\title{
Odeim y Oido en Nocturno de Chile de Roberto Bolaño
}

\section{Odeim and Oido in Nocturno de Chile by Roberto Bolaño}

\author{
Karim Benmiloud \\ Université Paul-Valéry Montpellier III. Francia \\ kbenmil@club-internet.fr
}

Resumen -El artículo se propone estudiar el funcionamiento del dúo Odeim-Oido en la novela Nocturno de Chile de Roberto Bolaño, como protagonistas y enigmas lingüísticos que hay que descifrar. Si toda la crítica coincide en descodificar la pareja en Miedo/Odio, se trata de ver cómo la misma novela programa la descodificación mediante una serie de indicios y variantes léxico-semánticas muy elaboradas. El análisis también propone una descodificación de los códigos culturales que informan al dúo (película policial, cuento de hadas, mitología escandinava, etc.). La reflexión concluye con un análisis sicoanalítico de los dobles (externos e internos) en la novela.

Palabras clave: Anagrama, dictadura, Pinochet, miedo, odio.

Abstract - The following article will study how the couple Odeim-Oido works in the novel Nocturno de Chile by Roberto Bolaño, considering them as protagonists as well as linguistic enigmas to be decoded. If the critical approach manages to decode the couple in Miedo/Odio (Fear/Hate in Spanish), it will have to see how the novel programs the decoding process through a number of elaborated signs and lexical-semantic variants. The essay will also try to decode de cultural signs that lead us to this couple (detective films, fairy tales, Scandinavian mythology, etc.). The article will end with a psychoanalytical analysis of doubles (inner doubles and external ones) present in this novel.

Keywords: Anagram, dictatorship, Pinochet, Miedo (fear), Odio (hate). 
Democracy means that if the doorbell rings in the early hours, it is likely to be the milkman

Winston Churchill

A partir del modelo constituido por el mentor del narrador, que posee una doble identidad bajo la forma de un verdadero nombre, González Lamarca, y de un seudónimo de crítico, Farewell, Nocturno de Chile es, como se sabe, una novela en que los dobles se multiplican al infinito y acaban por pulular. Como en este caso preciso, el doble suele ser constitutivo del mismo personaje, bajo la forma de una identidad segunda, un seudónimo o un nombre de pluma. Tal es el caso del propio narrador, que posee como su maestro una doble identidad de sacerdote-poeta con nombre oficial (Sebastián Urrutia Lacroix) y de crítico con seudónimo (H. Ibacache). En este caso, el doble es una parte del ser, o una de sus facetas, o sea que el hombre y su doble no constituyen sino una sola persona ${ }^{1}$. Esta lectura del doble recuerda obviamente el epígrafe de Chesterton, "Quitese la peluca", que remite a la vez al tema del doble y al tema de la disimulación, de la máscara y del disfraz, como si una identidad dada siempre escondiera otra, más verdadera, más auténtica pero también más inquietante².

Pero el doble también puede serle externo al personaje, bajo formas diversas ${ }^{3}$. En el caso del narrador Sebastián Urrutia Lacroix, estos dobles son numerosos y variados: es el joven poeta nerudiano (a quien podemos imaginar marcado por un compromiso político opuesto al del narrador); es también Sordello (que, a diferencia del narrador, se atrevió a desafiar a los poderosos sin temerlos); y es por fin Sebastián, el hijo mayor de María Canales y James Thompson, que lleva el mismo nombre que el narrador («mi pequeño tocayo» $)^{4}$ y que, gracias a un desplazamiento, desvela en realidad la responsabilidad y la culpa del propio narrador: «mi pequeño homónimo, que miraba sin ver mientras era transportado en brazos de su horrible nana, los labios sellados, los ojos sellados, todo su cuerpecito inocente sellado, como si no quisiera ver ni oír ni hablar en medio de la fiesta semanal de su madre» (134). En este caso, huelga decir que este homónimo, cuya inocencia el narrador se complace en subrayar, designa por lo contrario en clave secreta la misma naturaleza de la culpa del «héroe», es decir el que no haya visto nada ni oído nada en casa de María Canales, la mujer que, arriba, en su salón, organizaba veladas literarias mientras abajo, en el sótano, se interrogaban, torturaban e incluso asesinaban a opositores al régimen de Augusto Pinochet. De ahí la denegación final del narrador: «Yo hubiera podido decir algo, pero yo nada vi, nada supe hasta que fue demasiado tarde» $(142)^{5}$.

A veces, el nombre del doble difiere apenas del nombre de origen, como es el caso de James/Jimmy Thompson, el esposo de María Canales, que aparece en uno de los últimos episodios de la novela.

2 Sobre la oreja monstruosa que esconde en realidad este epígrafe (en el texto original de G. K. Chesterton), remitimos a «Figures de la mélancolie dans Nocturno de Chile» (Benmiloud, 127-129).

Para esta distinción entre dobles internos y externos, retomamos aquí la nomenclatura propuesta por Pierre Jourde y Paolo Tortonese en el capítulo V, «Le double dans le récit», de su libro (91-109).

4 «la verdad es que el mayor, que se llamaba como yo, Sebastián, no se parecía a ninguno de sus progenitores [...]» (127); «el niño Sebastián, mi pequeño tocayo [...]» (129); «aquel niño, mi pequeño homónimo» (134); «Y pensaba en los niños, sobre todo en mi pequeño tocayo, que crecía casi a su pesar» (135).

5 Al respecto, remitimos al artículo ««Sordel, Sordello, ¿qué Sordello?» Forme et fonction d'un leitmotiv dans Nocturno de Chile», y especialmente a la conclusión, en la que se analiza el extraño estribillo «Sordel, Sordello, ¿qué Sordello?» como una materialización poética en el relato del «regreso de lo reprimido», en el sentido freudiano de la expresión, o sea como el regreso de la culpa del narrador, que gira precisamente en torno a su sordera simbólica (Benmiloud, 157). 
Obviamente, «el Señor Odeim» y «el Señor Oido» también aparecen en la novela bajo el signo del doble. Si no son verdaderos dobles del personaje del narrador, son en cambio dobles el uno con respecto al otro, como lo indica el hecho de que aparezcan casi al mismo momento en la novela, que estén después presentados como «socios» y que se vuelvan por fin indisociables (como lo muestra la intrincación progresiva de sus dos apellidos a lo largo de las páginas en las que tienen protagonismo). Es significativo apuntar que se pasa del único "señor Odeim» al doble «señor Odeim / señor Oido", y luego de estas dos identidades yuxtapuestas a los «señores Odeim y Oido» $(106,113,119)$, antes de llegar a la única apelación «Oido y Odeim» (120), a los que el narrador acaba por quitar el título de «caballeros» ${ }^{6}$. Distintos en un principio, acaban por convertirse en una pareja inseparable cuyas apariciones hacen pensar en las de hermanos gemelos o siameses.

Su existencia como «dobles» o como "pareja» también viene confirmada por la brevedad de su apellido, por una parte (cuatro letras para uno, cinco letras para el otro), y por la inicial O que comparten, por otra (que también es la conjunción «o» de la cópula o de la disyuntiva, muy frecuente por lo demás en la obra) $)^{7}$. Pero, de manera más llamativa aún, también se impone la idea del doble o del espejo porque - como lo ha señalado ampliamente la crítica- su apellido es reversible y deja aflorar, para ambos, una identidad segunda o secreta: leído al revés Odeim se transforma en Miedo, mientras que Oido se convierte en Odio. Por este doble motivo estructural y hermenéutico, el Señor Odeim y el Señor Oido son pues la expresión paradigmática del doble en la novela, por ser a la vez dotados de un doble externo (su acólito) y de un doble interno o de una segunda identidad (aquí, por lo demás, muy inquietante).

\section{ALGUNOS INDICIOS HACIA LA REVELACIÓN}

De esta doble construcción especular y de esta reversibilidad da cuenta, por cierto, la primera frase - también reversible- del relato que hace el narrador de su encuentro con Odeim: «Encontré al señor Odeim (o el señor Odeim me encontró a mí) en una calle amarilla» (74). En cuanto al tema del doble, viene reforzado en el plano estilístico por un constante juego con los dobletes semánticos o los dobles sinonímicos a lo largo del relato de los vínculos del narrador con estos dos curiosos personajes (Y/O). Por lo tanto, no en vano trabajan ellos en una empresa de exportaciones e importaciones (figuras comerciales de la reciprocidad y de la reversibilidad de los intercambios): «Fue por aquellos días cuando conocí al señor Odeim y más tarde al señor Oido. Ambos gestionaban [...] una empresa de exportaciones e importaciones» $(74)^{8}$.

«Un tono distinto del que habían empleado días atrás los señores Odeim y Oido, que a fin de cuentas no eran unos caballeros» (119).

Al respecto, Fernando Moreno apunta acertadamente: «se destaca la múltiple presencia de oraciones construidas en torno a la conjunción ‘o’, para expresar alternativas, elección, indiferencia o desconocimiento» (Moreno, 209).

8 Se trata de una característica fundamental de los dos personajes: «La oficina de importación y exportación estaba en un cuarto piso» (78); "Nosotros nos dedicamos a los negocios de importación y exportación, pero también tocamos otros rubros, dijo el señor Odeim» (80). Sobre la reversibilidad de los intercambios y de los trayectos, véase la salida del narrador en barco, marcada desde los inicios por la 
Y tampoco es una casualidad si exportan machas a Francia $y$ a Alemania; si el narrador les fue recomendado por el padre Errázuriz y el padre Muñoz Laguía; si Odeim invita al narrador a un primer restaurante (Mi Oficina) y luego a un café (Haití); es decir si las páginas dedicadas a Odeim y Oido vienen puntuadas y estructuradas por figuras estilísticas binarias y bimembraciones. Para dar un buen ejemplo de ello, citemos también estas dos frases:

Me dijo que le había hablado de mí el padre García Errázuriz (1) y el padre Muñoz Laguía (2), a quienes tenía yo en alta estima (1) y de cuyos favores gozaba (2), y que estos sabios varones [...] pensa[ban] que un viaje prolongado por el viejo continente era lo más indicado para devolverme algo de la alegría (1) y de la energía (2) que había perdido (1) y que a ojos vistas seguía perdiendo (2) [...]. Al principio me mostré perplejo (1) y renuente (2), [...] pero acepté subirme a su auto (1) y dejarme conducir (2) [...] (75).

Pero, para evitar cualquier pérdida de sentido, y para que el lector no se pierda la lectura al revés, el autor se toma la molestia de sembrar algunos indicios que deben conducir a la revelación Odeim/Miedo, Oido/Odio. Así que se lee, desde las primeras páginas de la novela: «Tampoco sabía qué libros llevar para leer en el tren de ida y de vuelta, tal vez una Historia de Italia para el viaje de ida, tal vez la Antología de poesía chilena de Farewell para el viaje de vuelta. O tal vez al revés» (15-16). O también en el último tercio de la obra: «Hoy gobierna un socialista y vivimos exactamente igual. Los comunistas [...] los democratacristianos, los socialistas, la derecha y los militares. $\mathrm{O}$ al revés. ¡Lo puedo decir al revés! ¡El orden de los factores no altera el producto!» (121).

Asimismo, apenas introducido el «señor Odeim», observamos que el novelista elige describirlo como un hombre mediano, «de mediana edad, de estatura normal, ni flaco ni delgado, con una cara corriente», mestizo (mitad indígena y mitad europeo) «en donde apenas predominaban un poco más los rasgos indígenas que los rasgos europeos» (75) y que lo coloca significativamente en medio de la calle: «Al volverme lo vi: [...] me hacía señas en medio de la calle amarilla, a no demasiada distancia [...]» (75). Al hacerlo, el autor empieza a esbozar el retrato, no de «monstruos», sino de estos «hombres medianos", comunes y corrientes, y aparentemente insignificantes, que el contexto histórico hace caer del lado del $\mathrm{Mal}^{9}$ y que llevan una parte de responsabilidad considerable en el advenimiento y en el mantenimiento de la dictadura de Pinochet en Chile (con la cual, como sabemos, Odeim y Oido acabarán teniendo una relación muy estrecha). Pero el sustantivo "medio", que aparece aquí unas líneas después de la aparición del Señor Odeim, tiene obviamente como función descartar una primera solución anagramática para el problema planteado por la identidad misteriosa de Odeim ${ }^{10}$. En otros términos, la identidad secreta de Odeim no puede ser Medio, ya que este anagrama resolutivo nos es entregado inmediatamente después del enigma. Lo cual es tanto más verdadero cuanto que la palabra «medio» viene después repetida justo antes de la introducción del segundo enigma,

misma reversibilidad: «Una mañana me despedí de mi anciana madre y tomé el tren a Valparaíso, en donde embarqué en el Donizetti, barco de bandera italiana que hacía la ruta Génova-Valparaíso-Génova» (81-82).

9 Hannah Arendt le dedicó a esta cuestión de la banalidad del mal páginas decisivas: en 1951 en Los orígenes del totalitarismo (publicados en tres volúmenes: Sobre el antisemitismo; El Imperialismo; El Sistema totalitario); y más tarde en Eichmann en Jerusalén. Un estudio sobre la banalidad del mal, en 1961.

10 Antes de la ocurrencia de la página 75, la palabra «medio» sólo aparece en las páginas 12, 23, 45, 52, 59 (dos veces) y 63; después de la página 75, aparece más frecuentemente: 78, 82, 98, 103, 119, 128, 134, $136,142,148$ (dos veces). 
es decir la presentación del narrador al (también misterioso) doble de Odeim, el «señor Oido»: "mi mecenas daba unos golpecitos con la segunda falange del dedo medio en los cristales esmerilados de la oficina de su socio. Una voz chillona dijo adelante. Pasemos, me dijo el señor Odeim. El señor Oido estaba sentado detrás de una mesa metálica [...]» (78: el énfasis es nuestro).

De forma que la palabra «medio» es indisociable tanto de la primera aparición del señor Odeim como de la primera aparición del señor Oido. Más adelante, otro ademán efectuado con el «dedo medio", pero esta vez por el señor Oido, revela la importancia de la palabra «medio» en la economía onomástica de la novela: «El señor Oido se sirvió más té y llamó con un chasquido del pulgar y el dedo medio a la empleada para que le trajera un poco de leche» (103: el énfasis es nuestro). Si bien el doblete Odeim-medio funciona de forma estructurante en un primer tiempo (como indicio convergente de la presencia subliminal del Miedo), hay que esperar el final de la novela para ver acercarse, no tanto Odeim/miedo (sería demasiado apresurado), sino, en un sueño del narrador, «el árbol que se alzaba en medio de aquel patio descomunal» y los llantos del Padre Antonio, fuente para Urrutia de «un miedo inexplicable en el alma» (136), es decir el simple doblete medio/miedo. Luego, de forma más clara aún, es también el miedo (que el narrador pretende no haber sentido) el que se encuentra asociado con el... Middle West americano: «Yo no tuve miedo. [...] Más tarde a Jimmy [...] lo sacaron de la cárcel y lo pusieron en un programa de protección especial de testigos. [...] ¡Como si los generales de Chile pudieran extender sus tentáculos hasta las pequeñas poblaciones del Medio Oeste norteamericano para acallar a los testigos incómodos!» (142: el énfasis es nuestro).

Como lo señala este último ejemplo, del señor Odeim al «dedo medio», pasando por el «Medio Oeste norteamericano», todo nos conduce hacia la resolución del enigma, como lo sugieren también de forma subliminal las mayúsculas de «Medio Oeste» (especialmente la $\mathrm{O}$ ), que debe recordar tipográficamente la mayúscula del patrónimo Odeim e incitarnos a un trabajo hermenéutico sobre las letras y los anagramas (Odeim / Medio / Miedo).

\section{FUNCIÓN DE LOS PERSONAJES: DOS MISIONES}

Si nos interesamos ahora por el papel de los dos personajes en la diégesis, observamos que son ellos los que entran en contacto con el narrador: «[...] oí que alguien me llamaba. Al volverme lo vi» (74-75). No se emplean en vano estos dos verbos de percepción (oír/ver) porque, a diferencia de su actitud en casa de María Canales, el narrador no tiene aquí ninguna dificultad para ver y oír y, como lo veremos después, entender lo que quieren de él. En este sentido, y ya desde este momento, el narrador es culpable: culpable de ver, oír y entender donde y cuando le conviene hacerlo.

Simultáneamente, es evidente que el señor Odeim y el señor Oido son el arquetipo de los agentes o de los esbirros en que se apoyan todas las dictaduras: es decir que no solo son hombres discretos, empeñados, eficaces, sino también individuos inquietantes, amenazadores y altamente peligrosos ${ }^{11}$. La manera en que abordan al narrador hace pensar

11 «Eran eficientes, de eso me di cuenta en el acto, pero carecían de sutileza» (81). 
en un verdadero secuestro: «Al principio me mostré perplejo y renuente, pues los intereses del señor Odeim no podían diferir más de los míos, pero acepté subirme a su auto y dejarme conducir hasta un restaurante [...]» (75). Luego es agarrando firmemente al narrador como el señor Odeim deja precipitadamente el primer restaurante para llevarlo a un segundo: «[...] al poco rato salimos apresuradamente del local sin que quedara claro del todo el motivo de nuestra retirada, y paseamos tomados del brazo por las calles aledañas hasta llegar a otro restaurante [...]» (76). Y es una vez más cogiéndolo del brazo como Odeim lleva después al narrador a conocer al señor Oido: «Después el señor Odeim me cogió del brazo y sin saber cómo me vi otra vez en la calle, caminando a su lado. Voy a presentarle a mi socio, el señor Oido, dijo» (78).

Entre las otras características inquietantes de los dos personajes, mencionemos las informaciones recopiladas por Odeim sobre el narrador antes del encuentro/secuestro (sobre sus gustos literarios, sus amistades, su trabajo, etc.), informaciones de las que no duda en valerse para intimidarlo o presionarlo: «[...] se dedicó a hablar de gente que yo conocía, [...] en un intento de hacerme sabedor de que estaba al tanto de más de un aspecto de mi mundo, no solo el eclesiástico sino también el de las afinidades electivas, e incluso el laboral, pues también nombró al redactor jefe del diario en el que yo publicaba mis crónicas» (75-76). Citemos también la fuerza de «persuasión» del señor Odeim (claro eufemismo, ni que decir tiene), a la que el narrador acaba por ceder: «aunque quise protestar, negarme, el señor Odeim sabía ser persuasivo cuando quería» (77). Una fuerza de persuasión que no pasa necesariamente por el discurso, sino, como se verá, por los ademanes, y que es por lo tanto un signo anunciador de la amenaza física que encarnan los dos sicarios. Se podrían añadir asimismo las alusiones hechas por Oido sobre los orígenes familiares del narrador, que también pueden remitir a una previa investigación y a la constitución de un verdadero «informe» por parte de los dos hombres ${ }^{12}$.

Como en una pareja de interrogadores o de policías, se observa también una estricta repartición de los roles entre un Odeim amable y conciliador y un Oido firme e inquietante o amenazador, según el famoso esquema good cop / bad cop de las películas hollywoodenses. A saber que, en las reglas codificadas por el género (policial por lo general), y especialmente en su modalidad cinematográfica, al policía amable y conciliador le toca entablar una relación privilegiada con el sospechoso y por tanto conseguir que diga todo lo que sabe (e incluso, por supuesto, si es el autor del crimen, incitarle a confesarlo todo). Pero, en el caso en que solo se trata de presionar al interrogado, esta estrategia también tiene otra meta: incitarle de forma más sutil a que haga lo que quieren que haga. Por ello, no en vano desde este primer encuentro entre el narrador y el frío señor Oido ${ }^{13}$, es el señor Odeim quien le regala cigarrillos a Lacroix, para tratar de calentar la atmósfera (en estas circunstancias, como se sabe, ofrecer un cigarrillo es un acto que tiende a bajar la tensión y esbozar cierta complicidad entre el interrogador y su "preso»): «El señor Odeim sacó una cajetilla de cigarrillos. El señor Oido explicó que hacía unos diez años había dejado de fumar para siempre. Yo rechacé el cigarrillo que el señor Odeim me tendía» (80). Asi-

12 «Usted es el padre Urrutia Lacroix. El mismo, dije yo. A mi lado, el señor Odeim sonreía y asentía silenciosamente. Urrutia es un apellido de origen vasco, ¿no? Efectivamente, dije yo. Lacroix es francés, claro. El señor Odeim y yo asentimos al unísono" (79).

13 Que, por supuesto, viene del frío: «Y pequeños finlandeses y pequeños lituanos atravesándolos incesantemente, dijo el señor Oido. De día y de noche. A la luz de la luna o a la luz de unas humildes teas. Sin ver nada, de memoria. Sin sentir el frío que por esas latitudes se mete hasta el tuétano, sin sentir nada, simplemente vivos y en movimiento» (79). 
mismo, el señor Odeim se caracteriza sistemáticamente por su actitud calurosa, cuando no afectuosa, para con el narrador: «El señor Odeim me palmeó una pierna. El gesto fue cariñoso pero yo casi pegué un salto» $(104)^{14}$.

Una vez destinado a su misión europea — una misión al parecer muy bien gratificada ${ }^{15}$ y cuya duración no ha sido limitada, porque, inicialmente prevista para un año, «el plazo podía ampliarse hasta un año y medio» (81)—, el señor Odeim sólo se manifiesta de vez en cuando mediante cartas harto misteriosas (cartas de las que, como podemos imaginarlo, y pese al secreto que les rodea, dudamos mucho de que las hayan traído palomas mensajeras, dada la misión que ha aceptado el narrador). Dichas cartas aclaran a su vez el papel organizador de Odeim en la misión que le ha sido asignada a Urrutia Lacroix: «El padre Pietro [...] me explicó que el señor Odeim le había escrito una misiva avisándole de mi llegada» (84). El vínculo entre el señor Odeim y el narrador permanece sin embargo a la vez estrecho y ambiguo:

[...] luego me entregaron una carta que venía dirigida a mí, escrita por el señor Odeim, en donde me preguntaba qué tal Europa, qué tal el clima y las comidas y los monumentos históricos, una carta ridícula que sin embargo parecía encubrir otra carta, ésta ilegible, más seria, y que despertó en mí gran preocupación pese a no saber qué decía la carta encriptada ni tener plena seguridad de que realmente existía, entre las palabras de la carta ridícula, una carta encriptada (88-89; el énfasis es nuestro) ${ }^{16}$.

Una vez más, no cabe la menor duda de que esta(s) carta(s) encriptada(s) designan indirectamente a los personajes que las escribieron, cuyo apellido también exige un desciframiento o una verdadera descodificación. En cuanto a la misión, ella consiste, ya lo sabemos, en la protección de las iglesias de la Vieja Europa contra los desgastes cometidos por las deyecciones de las palomas, gracias al uso de aves rapaces, y más precisamente de halcones. Algunos exégetas, como Pablo Berchenko (17), quisieron ver en ello una metáfora de la lucha de la Iglesia conservadora en contra de la Teología de la Liberación en boga por los años setenta, o sea la imagen de una represión política y religiosa muy contextualizada. En un brillante artículo titulado «Jünger et la technique dans Nocturno de Chile», publicado en Les astres noirs de Roberto Bolaño, Raphaël Estève (154-157) ha analizado esta depredación de los pájaros contaminadores por halcones como una metáfora de la irrupción de la técnica, y más precisamente, del «arraisonnement du réel par la technique», a partir de una teoría avanzada por el propio Ernst Jünger y desarrollada después por Heidegger (siendo el «arraisonnement» entendido a la vez como racionalización y matematización, existe pues una relación estrecha entre las actividades económicas de importaciones y exportaciones de Odeim y Oido y la misión eminentemente técnica del narrador).

14 Véase también el momento en que Odeim y Oido le presentan su nueva misión: «Miré al señor Odeim buscando ayuda. Éste me hizo un gesto con los ojos que no entendí: podía ser un gesto de acatamiento o un gesto de complicidad [...]. La verdad es que ahora tengo muchísimo trabajo acumulado, dije. No se haga el cartucho con nosotros, dijo el señor Oido, éste es un trabajo que nadie puede rechazar. Que nadie querría rechazar, dijo el señor Odeim conciliador» (104-105, el énfasis es nuestro).

15 «Cada mes se me pagaría mi sueldo completo, más un plus extra acorde con los gastos superiores que tendría que afrontar en Europa. [...] Me tomé mi tiempo para despedirme de mis amigos, que no daban crédito a tanta suerte» (81).

16 Véase también más adelante: «De vez en cuando, y sin que viniera a cuento, el señor Odeim me mandaba una cartita» (94). 
De regreso a Chile después de cumplir su misión, el narrador es contactado una vez más por el señor Odeim y el señor Oido, después del golpe militar del 11 de septiembre de 1973. Otra vez, los dos hombres irrumpen sin avisar en la vida de Sebastián Urrutia Lacroix, y lo abordan una mañana, al salto de la cama, como si vinieran a arrestarlo: «Una mañana, precisamente, me dijeron que tenía visitas que me esperaban en la sala. Terminé de lavarme y bajé. Sentado en una banca de madera pegada a la pared vi al señor Odeim. De pie, [...] se hallaba el señor Oido con las manos cruzadas en la espalda. [...] Los invité a desayunar. Sorprendentemente dijeron que ya hacía rato que habían desayunado, aunque el reloj de pared apenas marcaba unos minutos pasadas las ocho» (102).

Como puede observarse, estos hombres desconocen por completo la cita como forma social y "civilizada» de encuentro. No sólo se presentan de improviso en casa de su interlocutor, sino que lo hacen a deshora, poco después de las ocho de la mañana, a la hora en que la gente normal está desayunando (lo que plantea la cuestión de saber lo que hicieron durante la noche): «Accedieron a tomar un té conmigo, sólo por acompañarme. Mi desayuno no consiste en mucho más que eso, les dije, un té solo, tostadas con mantequilla y mermelada, y un jugo de naranja. Un desayuno equilibrado, dijo el señor Odeim» (102). Como lo dijo alguna vez Winston Churchill, en una frase memorable que pusimos en epígrafe (recordemos que un episodio importante de la novela transcurre en el París ocupado de la Segunda Guerra mundial): «La democracia es el sistema político en el cual cuando alguien llama a la puerta de calle muy temprano por la mañana, se sabe que es el lechero». Aquí, el simple detalle de la hora en que Odeim y Oido le «visitan» al narrador muestra que el régimen en que se desenvuelven es una dictadura. Y la amenaza que representan va a ser subrayada porque el señor Oido se le impone al narrador bajo el signo de la voracidad. Después de negarse a compartir el desayuno de Lacroix, y en el silencio más absoluto, el señor Oido se pone a devorar una tras otra todas las tostadas de su huésped: «El señor Oido había cogido una de mis tostadas y la estaba untando de mantequilla. [...] El señor Oido le dio un mordisco a la tostada [...]. El señor Oido se acabó de tres mordiscos la tostada y empezó a ponerle mantequilla a otra. [...] El señor Oido se sirvió más té y llamó con un chasquido del pulgar y el dedo medio a la empleada para que le trajera un poco de leche. [...] ¿Sabe usted algo de marxismo?, dijo el señor Oido tras limpiarse los labios con la servilleta» (102-103).

$\mathrm{Ni}$ que decir tiene, la amenaza encarnada por el señor Oido se expresa aquí en clave abiertamente paródica, en virtud del principio según el cual un hombre que se presenta a casa de uno, sin previo aviso, a la hora del desayuno, para comérsele las tostadas sólo puede ser intrínsecamente malo. Para insistir en el carácter paródico de esta escena (como es por ejemplo la del taller literario con Augusto Pinochet), digamos que si el lector todavía tenía cualquier duda sobre las malas intenciones de los señores Odeim y Oido, esta escena de devoración transforma de inmediato al señor Oido en «lobo» de la fábula cuyo feroz apetito debe servir de clara advertencia a los lectores más jóvenes. (Al respecto, queda claro que la escena es paródicamente «traumatizante»).

Como lo recuerdan acertadamente los autores del Dictionnaire des symboles, la simbología del lobo nos conduce derecho al mundo de los Infiernos: «este aspecto ctoniano o infernal del símbolo [del lobo] constituye su otra cara principal, [...] que sigue dominante en el folclore europeo, como lo muestra, por ejemplo, el cuento de Caperucita roja». También añaden este detalle que nos puede interesar: «esta simbología del devorador también es el de las fauces o de la garganta («la gueule»), imagen iniciática y arquetípica, 
vinculada con el fenómeno de la alternancia día-noche, muerte-vida [...]. La garganta del lobo es la noche, la cueva, los infiernos» (Chevalier y Gheerbrant, 583) ${ }^{17}$. Salidos del mundo de la noche y de los Infiernos, los señores Odeim y Oido son pues lobos dignos de los cuentos populares, que firman mediante esta caracterización su pertenencia al mundo del Mal.

Se trata pues ahora de dar clases de marxismo a Augusto Pinochet y a la Junta Militar. Más que la primera, esta segunda misión identifica ahora claramente la colaboración y la complicidad de Sebastián Urrutia Lacroix con la dictadura, así como la discreción que los dos hombres exigen de él anuncia - y significa hiperbólicamente- su silencio culpable frente a los gritos de las víctimas torturadas y asesinadas: «Un servicio que se realiza en la oscuridad y la mudez, lejos del fulgor de las medallas, añadió. Hablando en plata, un servicio que debe llevarse a cabo con la boca cerrada, dijo el señor Oido. Punto en boca, dijo el señor Odeim. Labios sellados, dijo el señor Oido. Silencioso como una tumba, dijo el señor Odeim» (106).

Aunque los dos acólitos no le instan a nada más que no divulgar que va a dar clases particulares a los miembros de la Junta y al mismísimo Pinochet, bien se entiende que el silencio que se le exige aquí compromete toda su conciencia y vale para todos los renunciamientos posteriores. Esta oscuridad y esta afasia que acepta, esta boca cerrada, estos labios sellados y este silencio de tumba (nunca mejor dicho), designan también por anticipado tanto los del desgraciado preso torturado en la casa de María Canales, como los del futuro testigo Urrutia Lacroix, que permanecerá ciego, sordo y mudo y pretenderá después que no sabía nada de lo ocurrido en el sótano.

Como ya lo vimos en ««Sordel, Sordello, ¿qué Sordello?»: formes et fonction d'un leitmotiv dans Nocturno de Chile» (Benmiloud, 157), por este motivo simbólico es por lo que el señor Oido recusa el acento que transformaría indebidamente su patrónimo (Oido) en oído (oreja), es decir en órgano sensorial susceptible de oír y recoger los gritos y los llantos de las víctimas torturadas y asesinadas tanto en los locales de la policía secreta como en el sótano de María Canales: «Yo soy el señor Oido, me dijo entonces, Oido, no Oído. Está claro, dije yo» (79). Antes de aquel encuentro, es significativo observar que la primera aparición del sintagma "el señor Oido» en la novela aparece inmediatamente seguido por una frase que señala la interferencia auditiva supuestamente sufrida por el narrador: «Voy a presentarle a mi socio, el señor Oido, dijo. Me zumbaban las orejas» (78). Asimismo, cuando el señor Odeim y el narrador están caminando para ir a visitarle al señor Oido, se cruzan con dos «figuras» que significan y programan una vez más la ceguera y la sordera: «[...] de vez en cuando, en los portales, se escondía algún hombre con gafas oscuras, alguna mujer con un pañuelo en la cabeza» (78). Si las gafas negras nos remiten obviamente a la ceguera, de forma más sutil (y, por así decirlo, menos visible), el pañuelo en la cabeza remite a la sordera, en la medida en que, para no caerse, debe necesariamente cubrir las orejas.

En la medida en que funcionan en binomio o a dúo, y porque exigen simbólicamente del narrador este silencio cómplice frente a los gritos de las víctimas, los señores Odeim y Oido recuerdan por cierto a los agentes de la DINA, la siniestra policía secreta de la dictadura de Pinochet. Si se toma en consideración el hecho de que su jefe es extranjero, también es posible verlos como agentes de la CIA (o sea la Agencia de informaciones

17 Sobre la importancia de la «gueule» (las fauces o la garganta) en la onomástica bolañesca, véase Raphaël Estève (150-152). 
norteamericana) que han sido puestos a la disposición de Pinochet y que se valen de sus actividades comerciales como cobertura: «Ambos gestionaban por cuenta de un señor extranjero a quien nunca tuve el gusto de conocer una empresa de exportaciones e importaciones» (74). En todo caso, Sebastián Urrutia Lacroix es requerido para dar cursos de marxismo a la Junta militar, y una vez más la invitación o la convocatoria se asemeja a un secuestro, porque un coche viene a recogerlo de improviso a la salida del edificio donde trabaja:

Una tarde, al salir de la redacción del periódico, un automóvil me estaba esperando. Fuimos al colegio a buscar mis apuntes y después el auto se perdió en la noche de Santiago. Junto a mí, en el asiento trasero, iba un coronel, el coronel Pérez Larouche, que se encargó de entregarme un sobre que no quise abrir y que volvió a insistir en lo que ya me habían encarecido los señores Odeim y Oido: la discreción absoluta en todo lo referente a mi nuevo trabajo (106).

\section{INTERPRETACIONES SIMBÓLICAS}

Pero este aspecto contextual, que hace de Odeim y Oido secuaces de Pinochet y transposiciones literarias de agentes de la DINA o de la CIA, no prohíbe que consideremos dichos personajes en todas sus dimensiones alegóricas y simbólicas, y especialmente sus posibles resonancias mitológicas. Desde un punto de vista alegórico, es imprescindible señalar que Odeim y Oido encarnan este Mal absoluto que Roberto Bolaño figuró y escenificó obsesivamente en toda su obra novelística. A esa fascinación por el Mal le debemos sin lugar a dudas la llamativa galería de nazis y criminales fascistas de que dotó su obra, una galería en la que, debido a la potencia de la alegoría, el señor Odeim y el señor Oido ocupan desde luego un lugar privilegiado y destacado. De ahí que el propio Roberto Bolaño haya enfatizado en una entrevista el papel simbólico de estos dos personajes, apoyándose en una axiología casi evangélica en que aparecen significativamente ovejas y lobos:

Después de asumir los ropajes de tantas ovejas, me dan ganas de ponerme la piel de un lobo [Sebastián Urrutia Lacroix]. Ahora yo no creo que sean lobos realmente, ni el narrador ni gran parte de los personajes que aparecen en la novela, sino más bien náufragos. Hay unos cuantos lobos. El señor Oido y el señor Odeim son lobos al ciento por ciento y la Junta Militar chilena para qué te voy a decir. Pero los otros personajes son más bien seres extraviados, en el sentido en que todos estamos extraviados. Incluso cuando hablamos de lobos yo añadiría lobitos. Ni siquiera lobos. Porque el matiz está tal vez en que el terror lo sienten mucho más los lobitos («Si viviera en Chile» en Primera línea).

En la axiología de la que se vale Bolaño, las ovejas (las víctimas) se opondrían a los lobos (los verdugos), estos temibles lobos cuyo perfecto paradigma constituirían pues los señores Odeim y Oido. De hecho, «De lobos y corderos» también es el título de una brevísima fábula de Esopo, que el moralista francés Jean de la Fontaine retoma en el siglo XVII bajo el título «Les Loups et les Brebis» (Libro III, fábula 13) y cuya conclusión es terminante: «nous pouvons conclure de là / qu'il faut faire aux méchants guerre continuelle» («De alli que podamos concluir / que a los malos hay que darles guerra continua»). 
Sin embargo, para Bolaño, el Bien y el Mal no se oponen sistemáticamente de forma tan maniquea, porque el autor identifica o reivindica entre los dos polos que acaba de definir todo un abanico de posibilidades y matices. Incluso para los lobos, evoca en efecto un vínculo profundo con el «terror» que acaba convirtiéndolos en «lobitos», como si en última instancia la conducta de esos personajes también se explicara por resortes sicológicos internos (volveremos sobre ello). Pese a esto, esta ejemplar encarnación del Mal sigue eficiente y operativa en la construcción de la novela, ya que el narrador-personaje no duda en datar su caída a partir de su encuentro con los dos hombres que lo han corrompido: «¿Sabe un hombre, siempre, lo que está bien y lo que está mal? En un momento de mis cavilaciones me eché a llorar desconsoladamente, estirado en la cama, echándoles la culpa de mis desgracias (intelectuales) a los señores Odeim y Oido, que fueron los que me introdujeron en esta empresa» (113).

Es tiempo de decir que este polo negativo o malo que encarnan de forma ejemplar el señor Odeim y el señor Oido en su complementariedad antinómica, también se asienta en una posible intertextualidad cinematográfica: si recordamos que el señor Odeim y el señor Oido son, ante todo, mirados en el espejo, el señor Miedo y el señor Odio, que se caracterizan por un ademán de la mano o de los dedos (el pulgar y el medio), y que son por antonomasia una figura de terror para grandes y pequeños (piénsese en la escena paródica de las tostadas y, por supuesto, en su nombre en forma de acertijo), es posible sugerir que estos dos personajes también se inspiran en el falso pastor fanático encarnado por Robert Mitchum en The Night of the Hunter (La noche del cazador), la película de Charles Laughton estrenada en 1955, en que, como en Nocturno de Chile, la noche desempeña un papel fundamental.

En esta famosa película, el inquietante reverendo Harry Powell es en realidad un temible asesino que tiene las letras de las palabras «LOVE» y «HATE» (o sea AMOR y ODIO) tatuadas en la primera falange de cada uno de los dedos de sus manos, ilustración harto llamativa de la lucha entre el Bien y el Mal que se verifica en la tierra (en sus falsas predicaciones, enseña de hecho «una mano para bendecir y la otra para castigar»). Ilustración también de la lucha secreta que parte y desgarra el alma del propio personaje. El parentesco entre los señores Odeim y Oido y Harry Powell parece cuanto más pertinente que el café al que el señor Odeim le lleva al narrador se llama el «Haití» (lo que se asemeja a «HATE» en inglés, como en la película de Laughton). Y precisamente en el Haití es donde el narrador da rienda suelta a su odio más feroz hacia la plebe y el vulgo. Es más: los dos sentimientos alegorizados por Odeim y Oido, es decir el Miedo y el Odio, invaden al personaje en los dos lugares a los que le lleva sucesivamente Odeim. En el primer restaurante, «Mi Oficina», es el Miedo el que parece sobrecoger inexplicablemente a los dos personajes: «Después el señor Odeim tuvo un intercambio de palabras con el dueño de Mi Oficina y al poco rato salimos apresuradamente del local sin que quedara claro del todo el motivo de nuestra retirada [...]» (76). Luego, en el café «Haitî", el narrador se deja sumergir por el Odio, como preludio a su encuentro con el señor Oido:

El café insistió en que lo tomáramos en el Haití, que es un sitio infecto en donde se juntan todos los canallas que trabajan en el centro de Santiago, vicegerentes, vicedelegados, viceadministradores, vicedirectores [...]. Y hacia ese antro me vi arrastrado, yo, un hombre que ya tenía de alguna manera un nombre, que de hecho tenía dos nombres, y renombre [...] dejé que mi mirada vagara por el local carente de sillas. Algunos hombres me devolvie- 
ron la mirada. En los semblantes de algunos creí descubrir un dolor inmenso. Los cerdos también sufren, me dije. (76-77)

Así que en el «Haití» (HATE) es donde el narrador expresa más vehementemente su desprecio hacia los hombres subalternos y mediocres, figurados en esta enumeración por la repetición detestable del prefijo vice - (se sabe que el personaje gozará después de una relación privilegiada con el general Augusto Pinochet, del que será, sin la menor vergüenza, el cortesano más vil). En el «Haití» (HATE / ODIO), y en contra del precepto evangélico, Lacroix expresa con absoluta claridad su odio hacia sus prójimos, a quienes compara con cerdos (y a quienes, podemos imaginarlo, destina al matadero), mientras se envuelve en su gloria de hombre de letras que un breve alto en este lugar tan vulgar podría manchar y corromper. Si el Haití acaba revelándose como el lugar del Odio por excelencia, bien podría ser, gracias al juego de palabras translingüístico, un guiño de ojo al LOVE/HATE que Robert Mitchum lleva tatuado en sus falanges en La noche del cazador de Charles Laughton.

Ahora bien, en un plano más estrictamente mitológico, y para cambiar totalmente de horizonte cultural, Odeim y Oido tampoco dejan de hacer pensar en Odín, el dios escandinavo de la Guerra, al que las leyendas describen viejo, barbudo y tuerto (inscribiéndose esta última característica en la continuidad de esta recurrente incapacidad para ver que define tanto al narrador como a los señores Odeim y Oido). Dicha interpretación mitológica parece ser confirmada por el origen nórdico de Oido, que le confiesa al narrador: «¿Sabe de dónde proviene Oido? No tengo idea, dije yo. Aventure un lugar, dijo él. ¿De Albania? Frío, frío, dijo él. No tengo idea, dije yo. De Finlandia, dijo él. Es un nombre mitad finlandés y mitad lituano» (79).

Pero el parentesco con el dios Odín nos interesa cuanto más que, en la mitología nórdica, a éste también lo informan dos cuervos posados en sus hombros, Hugin (el Pensamiento) y Munin (la Memoria), que le cuentan cada mañana cuanto han visto de los nueve mundos. En el Panteón nórdico, es el dios de la rabia, de la astucia y de la victoria, y también un dios sombrío, conspirador, severo y temido. Pero, sobre todas las cosas, es el dios de los guerreros que recibe las almas de la mitad de los guerreros muertos en combate para convidarlas a un gran banquete nocturno: el banquete de Odín. Lo cual podría remitir a las escenas de comidas que Odeim y Oido comparten con el narrador, así como conectar secretamente estos episodios con el de la famosa Colina de los Héroes de Heldenberg (en la mitología nórdica, la otra mitad de los guerreros muertos es acogida por la diosa Freyja). En todo caso, la intencionalidad del juego secreto con Odín, el dios escandinavo de la guerra, no deja lugar a dudas, ya que Odín ya aparecía en Estrella distante (1996), como título de una revista criptonazi en la que se supone que sigue publicando el criminal Carlos Wieder después de su misteriosa desaparición: «Hibernia, Germania, Tormenta, El Cuarto Reich Argentino, Cruz de Hierro, [...], Diptongos y Sinalefas, Odin, Des Sängers Fluch» (Bolaño, 105).

Pero si admitimos que Odeim y Oido son alegorías, es decir una «ficción en virtud de la cual una cosa representa o significa otra diferente» o, en el sentido pictórico o escultórico, una «representación simbólica de ideas abstractas por medio de figuras, grupos de éstas o atributos» (Diccionario de la Real Academia Española), es de recalcar que el novelista se vale de las alegorías del Miedo y del Odio para evocar los pilares en que se apoya la dictadura de Pinochet, y por extensión cualquier dictadura. Es el Miedo al Otro (el comunista, el intelectual, el rival político, el opositor, etc.) el que engendra el Odio, y 
el miedo conjugado con el odio los que, juntos, dan a luz al horror de la dictadura. Por ello mismo, en el relato propuesto por Bolaño, el miedo es primero y el odio sólo llega después: «Fue por aquellos días cuando conocí al señor Odeim y más tarde al señor Oido» (74). Por otra parte, como lo ha destacado el crítico Pablo Berchenko (19), el Miedo y el Odio también remiten sintomáticamente a sentimientos que fueron ampliamente explotados y nutridos por la oposición a Salvador Allende antes y después de los años 70:

Ellos personifican la manipulación — realizada desde el extranjero- de las emociones y de las pasiones políticas (odio y miedo) que permitieron desestabilizar la vida política en Chile. Referencialidad que remite a las acciones secretas de la C.I.A, desde la primera campaña presidencial de E. Frei en 1964 hasta la dictadura de Pinochet. Tal fue la «campaña del terror» destinada a impedir la elección de S. Allende, o la campaña que hizo la oposición durante su gobierno bajo el eslogan «juntemos odio chilenos».

Pero, pensándolo bien, si Odeim y Oido son a la vez dobles externos (doble el uno del otro) y dobles internos (que acaban revelando una identidad secreta: Miedo y Odio), también lo son porque la Dictadura es ante todo el producto o el fruto político de pasiones íntimas, que se asientan y proliferan al interior de los mismos individuos. Antes del Odio, está el Miedo, por lo cual, para Bolaño, incluso el lobo más rabioso no escapa del miedo y de sus propios terrores (que no le quitan sin embargo ninguna responsabilidad en los crímenes que lo llevan a cometer). Así para el novelista chileno, aun el lobo más feroz acaba convirtiéndose en «lobito» invadido por sus propios terrores, y por tanto no puede constituir ningún modelo de fuerza: «Incluso cuando hablamos de lobos yo añadiría lobitos. Ni siquiera lobos. Porque el matiz está tal vez en que el terror lo sienten mucho más los lobitos» (Bolaño, 2000).

En otros términos, Odeim y Oido, Miedo y Odio, figuran en última instancia sentimientos que alberga el propio narrador, en su alma profunda, a imagen y semejanza de aquel «joven envejecido» - aquel hombre desdoblado y escindido cuyo segundo nombre (envejecido) contiene a su vez todas las letras del primero (joven) - del que se entiende al final de la novela que también es un doble más del narrador. Es sin duda alguna en el mismo corazón del narrador donde hay que ir a buscar el miedo y el odio, este miedo que es uno de sus atributos característicos y que va creciendo a lo largo de la novela ${ }^{18}$ y este odio (a los campesinos, a los pobres, a los niños, a los seres feos o deformes, etc.) que el narrador va repartiendo con igual «generosidad» en todo su relato. No en vano el final de la novela hace coincidir, más que el miedo, un verdadero terror apocalíptico con la revelación sobre la verdadera identidad del «joven envejecido", que no es otro que un doble del narrador: « $¿$ Esto es el verdadero, el gran terror, ser yo el joven envejecido que grita sin que nadie lo escuche?» (149-150). Ya que el miedo puede imputarse a la presencia, en el corazón del narrador, de otro "yo», de su mala conciencia o de su parte maldita, aparece claramente que el miedo del narrador (a los pudientes, y luego a la muerte) y que el odio rabioso del joven envejecido son una sola y misma cosa.

18 Véanse las numerosas ocurrencias del miedo en la novela: «Por un momento yo también sentí miedo» (17); «Sentí miedo y asco» (20); «[...] la inmovilidad de Farewell [...] fue adquiriendo para mí connotaciones de terror infinito o de terror disparado hacia el infinito, que es, por otra parte, el destino del terror, elevarse y elevarse y no terminar nunca y de ahí nuestra aflicción, de ahí nuestro desconsuelo, de ahí algunas interpretaciones de la obra de Dante, ese terror delgado como un gusano e inerme y sin embargo capaz de subir y subir y expandirse como una ecuación de Einstein» (63); "a mí me entraba un soplo de aire frío en el cuerpo y un miedo inexplicable en el alma» (136), etc. 
Dicho de otra manera, como el doblemente doble joven/envejecido, Odeim y Oido, a su vez, no son más que una proyección desdoblada del YO (Y/O) del narrador, un doble desdoblado primero externo, pero que acaba recobrando su sitio adentro, en el psiquismo del propio narrador. En términos sicoanalíticos, este doble desdoblamiento se caracterizaría por el rol preponderante que juegan la ambivalencia (amor/odio), la proyección, el narcisismo y la castración. Como lo recuerdan Pierre Jourde y Paolo Tortonese, en efecto, «la proyección consiste en atribuirle al otro lo que uno desea, o lo que uno se prohíbe desear, o no consigue asumir. [...] Lo que rechaza de sí mismo, lo que ignora de sí mismo, [el sujeto] lo vuelve a encontrar en una figura a la vez hostil, extraña, y familiar. En este sentido, el doble puede representar a la vez la posibilidad para el sujeto de encontrarse bajo una forma objetiva, y una manera de no identificarse con su deseo» (64-65; la traducción es nuestra) ${ }^{19}$.

El Miedo y el Odio bien son, en última instancia, sentimientos inherentes al narrador. Lo prueban tanto el miedo abismal a la muerte con que concluye la novela como el odio por fin asumido, bajo la forma de una sola y única ocurrencia del verbo «odiar» en toda la novela (ahí se resuelve el enigma Oido) y una breve (y última) frase que se asemeja a un juramento de odio: «Y entonces pasan a una velocidad de vértigo los rostros que admiré, los rostros que amé, odié, envidié, desprecié. Los rostros que protegí, los que ataqué, los rostros de los que me defendí, los que busqué vanamente. / Y después se desata la tormenta de mierda» (150).

\section{REFERENCIAS}

Benmiloud, Karim. «Sordel, Sordello, ¿qué Sordello?> Forme et fonction d'un leitmotiv dans Nocturno de Chile». La memoria de la dictadura. Fernando Moreno (coord.). Paris: Ellipses, 2006. 148-157. Medio impreso.

- «Figures de la mélancolie dans Nocturno de Chile». Les astres noirs de Roberto Bolaño. Karim Benmiloud y Raphaël Estève (coord.). Bordeaux: Presses Universitaires de Bordeaux, 2007. 109-134. Medio impreso.

Berchenko, Pablo. «El referente histórico chileno en Nocturno de Chile de Roberto Bolaño». La memoria de la dictadura. Fernando Moreno (dir.). Paris: Ellipses, 2006. 11-20. Medio impreso.

Bolaño, Roberto. Nocturno de Chile. Barcelona: Anagrama, 2000. Medio impreso.

—. «Si viviera en Chile, nadie me perdonaría esta novela» (entrevista con Melanie Jösch). PrimeraLínea. Sitio Web. 2000.

—. Estrella distante. Barcelona: Anagrama, 1996. Medio impreso.

Chevalier, Jean y Alain Gheerbrant. «Loup». En Dictionnaire des symboles. París: Robert Laffont, 2003. Medio impreso.

Esteve, Raphaël. «Jünger et la technique dans Nocturno de Chile». Les astres noirs de Roberto Bolaño. Karim Benmiloud y Raphaël Estève (coord.). Bordeaux: Presses universitaires de Bordeaux, 2007. 135-160. Medio impreso.

19 Para un acercamiento sicoanalítico al personaje del «joven envejecido», véase «Figures de la mélancolie dans Nocturno de Chile» (Benmiloud, 2007 : 130-133). 
Harendt, Hannah. Eichmann en Jerusalén. Un estudio sobre la banalidad del mal. Trad. de Carlos Ribalta. Barcelona: Lumen, 1967. Medio impreso.

Jourde, Pierre y Paolo Tortonese. Visages du double (un thème littéraire). París: Nathan Université, 1996. Medio impreso.

Moreno, Fernando. «Sombras... y algo más. Notas en torno a Nocturno de Chile». Roberto Bolaño, una literatura infinita. Ed. Fernando Moreno. Poitiers: CRLA/Archivos, 2005. 199-210. Medio impreso.

The Night of the Hunter. Laughton, Charles, dir. 1955. Medio fílmico.

Recepción: 7 de enero de 2010 Aceptación: 4 de marzo de 2010 